\title{
Religion and Realism in International Law: China's Perspective on the Israeli-Palestinian Conflict
}

\author{
Gai $\operatorname{Ran}^{1}$ \\ ${ }^{1}$ Zhongnan University of Economics and Law, Wuhan, P. R. China \\ Correspondence: Gai Ran, 182\# Nanhu Avenue, East Lake High-tech Development Zone, Wuhan 430073, P. R. \\ China. Tel: 86-18-600-429-206.
}

\author{
Received: March 11, 2015 Accepted: March 30, 2015 Online Published: May 22, 2015 \\ doi:10.5539/res.v7n9p10 URL: http://dx.doi.org/10.5539/res.v7n9p10
}

\begin{abstract}
The purpose of this article is trying to answer the following question: What else a State needs to consider, besides its international legal obligations, when developing its foreign policy? I hope to demonstrate how factors such as religion and realism affect a country's foreign policy by using the case of Israeli-Palestinian conflict and China's interactions with the two nations. China successfully adapt realistic attitude in making its middle-east policy. It supported Palestine for the ideology of anti-imperialism, but established relation with Israel for the need of national interest. In this article, I would give a general introduction of the history of China's relation with Palestine and Israel, including several key incidents that carry great significance in this triangular relationship. Trough my introduction, I hope to demonstrate how religion and realism affects a nation's foreign policies, as well as international law. I would discuss China's involvement in the Israeli-Palestinian conflict from the perspective of international relations. First, I will focus on the changes and evolvements of China's relationships with Palestine and Israel throughout history, and briefly discuss what China has done in the past with the two countries. Second, I will introduce how Chinese society views the Israeli-Palestinian conflict. In the end, proposals will be made for China's future policy in the region.
\end{abstract}

Keywords: international law, realism, Middle East, foreign policy, terrorism

\section{Introduction}

\subsection{Introducing the Problem}

What makes international law such a unique concept is that people has been expressing overwhelming doubts on its legal nature. The main reason for these skeptics is the fact that international law seems have no binding effect on sovereign states and a great power could carry out its own policy against its legal obligation without worrying the consequence. This point of view is hard to argue when we are facing so many international practices, which have evidently shown that "international law" is clearly not the only factor to be considered when a nation is developing its foreign policy.

The purpose of this article is not to defend the legal nature of international law, but try to answer the following question: What else a State needs to consider, besides its international legal obligations, when developing its foreign policy? I hope to demonstrate how factors such as religion and realism affect a country's foreign policy by using the case of Israeli-Palestinian conflict and China's interactions with the two nations. The two ideologies are like fire and water: the first heats things up while the second cools it down. In the Israeli-Palestinian conflict, religion made things go to the extreme while realism always brought people back. In addition, China successfully adapt realistic attitude in making its middle-east policy. It supported Palestine for the ideology of anti-imperialism, but established relation with Israel for the need of national interest.

In the Israeli-Palestinian conflict, the applicable rules and laws were tangled together. Both parties had invoked strong legal and political arguments for their causes. Moreover, this conflict is a reflection of the conflict between opposing religions and historical misfortunes.

In history, China has been taking the side of Palestine. Its firm and clear position was strongly supportive of the struggle for national rights of the Palestinian people. The CCTV (China Central Television) used to make statements constantly against Israel's unlawful use of force. There were mainly two reasons for this preference: First, China's foreign policy was strongly influenced, if not dominated, by ideology. Since Israel is in the camp 
of "western capitalistic imperialism", it was impossible for China, as a communist country, to side with it. Second, it was in the human nature to sympathize the weaker side. Therefore, at one point, Israel and Palestine was "black and white" for most of Chinese people. However, such cognition was soon to be changed when China adjusted its Middle East policy.

Nonetheless, China did not take it to the extent that it would fight against the "Jewish invasion" with Palestine side by side. This attitude was the reflection of China's realism philosophy in developing foreign policies. China decided to offer its support more on the level of morality, with no concrete assistance measure that would drag itself into the conflict. Our accusations against Israel were generally about its peace-breaking actions.

Another thing that held China back from fully supporting Palestine was many radical actions carried out by the Palestinian Liberation Organization (PLO). Chinese Premier Zhou Enlai has repeatedly expressed China's position when visiting PLO delegations: We were only opposing the policy of the Israeli government. We would not target Jewish people as enemies (Gang, 2010). China also raised harsh criticism against the civil aircraft hijacking and the killing of hostages along with other terrorist activities (Id.). Chinese leadership was also not happy about the "slogan" of "throwing Jews into the sea" (Id.). This position prevented China from going too far to the side of anti-Semitism.

After the concept of "terrorism" was introduced into international law, it has become a general consensus of the international community that terrorist activities were crimes against the entire human race. Because of the fight-back strategy adopted by some of the Palestinian militant groups, China became less supportive of Palestine's struggle, and started to emphasize the establishment of a two-State settlement, which requires the mutual recognition and peaceful co-existence of Israel and Palestine.

Once established the Reform and Opening up Policy, China's main focus immediately shifted to develop economy. The guiding principle of its foreign policy changed from ideology-oriented to maintain balance among all parties. Anything that was not directly related to economic growth was considered secondary for the Chinese leadership.

Nowadays, China's influence on the Israeli-Palestinian conflict is expanding and deepening, which is the result of its growing power. China's rapid development heavily depends on imported oil from the Middle East, and thus maintaining peace in the area has become a significant national interest for China. Moreover, the "Arab Spring" was an alarm bell for the Chinese government, which made it realize that expanding influence in the Arab world is necessary, both economically and politically.

Invited by the new leadership of China, Israeli Prime Minister Netanyahu arrived at Beijing on May 6 of 2013, just missed the Palestinian President Abbas, who finished his visit on the same day. It was disappointing that they did not have a chance to meet in China. The reason for such an arrangement was probably due to the fact that China still has little to offer for both sides, despite its eagerness to play a significant role in the region.

\subsection{Literature Review}

The research on China's Middle East policy at this stage is mainly focusing on the areas of history, bilateral relations, energy trade, regional hot topics, etc. Meanwhile, the research work is generally conducted from spheres of the government. The main purpose of researching diplomatic relations from the political perspective is to provide suggestions for the country's future policy.

This article mainly relies on reports of news and events in history, books and articles regarding Middle East, as well as archival materials, including several UN resolutions.

The book named "Overview of the History of People's Republic of China on Foreign Relations", written by Niu Jun, is extremely helpful. Since it gives and systematic introduction of China's foreign relations from 1949 to 2000. "Introduction on China's Contemporary Foreign Relations (1949-1999)", edited by Li Feng and Liu Ming, believes that China has always been in sympathy with Arab people. Chinese government has offered its support to Arab people's struggle for their national independence and liberation. Xie Lifu's "Middle East War" (1994) describes in detail about the Arab-Israeli war, and gives a general introduction on the position and attitude of the Chinese government. As the liaison of the Joint Action Opposed the US-British Invasion of Iraq and the convener of the Association on Labor Policy and Human Rights, Tang Shu's article named "Tribute to Edward Said: From the Opposition to Oslo Accord to Israeli-Palestinian Cohabitation" sincerely increases people's humanistic care of the Middle East conflict.

As to introducing terminologies and history events, this article relies on selective sources from the Internet. For instance, factual information can be found from Wikipedia pages and on-line news reports. This article also gathered many event analysis and commentaries from authoritative media's editorials. 


\subsection{Technique}

(1) Studying historic materials

When dealing with numerous materials that contain massive information, selective processing is needed. In this article, I will only cover events that carry significance and typicality. Moreover, I need to combine material-study with analysis, in order to avoid monotonous narrative and summary of the materials.

\section{(2) Case study method}

This method is closely linked with comparative analysis and historical method. Case study method is about discussing in-depth detailed information of one or more individual cases collected from an extensive background. Cases that are selected have to be typical and representative. It is the only way to ensure conclusion of the analysis would not be biased.

(3) Combining partial analysis with the general conclusion

This method aims at resolving the conflict between dispersion and uniformity of the research object. Since the research of international relations in this article is composed by a number of studies on individual cases, this method helps me to see the whole picture while discussing isolated events.

\section{Modern History of China's Relationships with Israel and Palestine}

\subsection{Sino-Palestinian Relation}

\subsubsection{China as a Strong Supporter of Palestine}

For Palestine, the essence of their struggle is to restore the legitimate national rights of the Palestinian Arabs. China has been a strong supporter of that cause since the 1960s, especially after it broke up with the Soviet Union.

Mao Zedong viewed the struggle of the Palestinian people as part of the "global revolution against Imperialism" (Wen, 2012). He once said during a meeting with Arab delegations that "the problem is not just about Israel, it is about who is behind Israel..." (Id.) Therefore, Mao's Palestinian policy was in line with his general position of anti-western capitalism. By supporting the Palestinian people, he was not only fulfilling a "noble duty as an internationalists" (Id.), but also "breaking the blockage against China imposed by imperialist countries". (Id.)

People's Daily, the official newspaper of Communist Party of China (CCP), published an article on October 6 of 1969, named "Maoism Is A Strong Weapon for the Palestinian People to Achieve Victory". The content of the article was probably exaggerating: it generally introduced how Palestinian militants were fighting Israel by using Mao's theory of guerrilla tactics. (People's Daily, 1969) However, it served as an evidence of China's public support for the liberation of Palestine.

After Beijing Government restored the seat of China in UN in 1971, it offered more political support to Palestine within the framework of international law. One significant incident was that China favored the passing of the United Nations General Assembly Resolution 3379 in 1975. This resolution, titled as "Elimination of All Forms of Racial Discrimination", labeled Zionism as "a form of racism and racial discrimination" (A/RES/3379, 1975). This "political victory" of Palestine carried significant meaning: it provided moral support and legitimacy to Palestine's struggle. Just as Arafat said during his secret visit to China in 1965: "Our resistance is not for military victory, but to prove our political existence" (Tang, 2003).

While being supportive of Palestine, China was inevitably faced with the problem of how to handle the relationship with Israel. Israel recognized the Communist government as the legitimate representative of China only one year after the establishment of PRC on October 1 of 1949. Ever since that time, Israel had been attempting to establish formal diplomatic relations with China. However, these endeavors were ignored by China due to the ideology difference and the general Cold-War environment. Mao set the guiding principle for China's policy towards Israel, which was not to recognize Israel as a State and not to establish diplomatic relations for the time being. This principle ensured China a certain degree of flexibility without the burden of promising not to recognize Israel forever. In March of 1965, Mao made it clear to Ahmad Shukeiri, the Chairman of Palestinian Liberation Organization (PLO), that China would not bear the general obligation of not recognizing Israel. In that way, China would not lose the initiative to establish diplomatic relations with Israel when the time was right.

\subsubsection{Attitude Changed}

China's attitude towards Palestine was slightly changed when Deng Xiaoping came to power in 1978. Supports for Palestinian militant groups were reduced and China started to emphasize the importance of peaceful dialogue. Although China remained sympathetic to Palestine, its supports were "continued in a more limited fashion". 
There were mainly two reasons for this change: first, the new leadership of China determined to end the hostility with western countries. Second, Deng set economic growth and development as the priority of the whole nation. China was in the great need of interacting with western countries, specifically Israel. From then, China started to call for a two-State solution as the final settlement.

Besides the attitude change, China remained in favor of the liberation of Palestine. After China restored its seat in the United Nations, it provided help to Palestine by using its influence as a permanent member of the Security Council. In August of 1980, China supported the adoption of United Nations Security Council (UNSC) Resolution 478 (S/RES/478, 1980), which condemns Israel's attempted annexation of East Jerusalem. In particular, it states that Israel's non-compliance with UNSC Resolution 476 (S/RES/476, 1980) and critics Israel's 1980 "Jerusalem Law" as "a violation of international law". The Jerusalem Law designated the city of Jerusalem to be Israel's "complete and united" capital. The Security Council did not recognize such declaration. All members were called upon to withdraw their diplomatic missions from the city.

On November 15 of 1988, China strongly supported the Palestinian Declaration of Independence despite the objections of Israel and the United Sates. China recognized Palestine as a sovereign State only 5 days after its Declaration of Independence (on November 20, 1988), and full diplomatic relations between China and Palestine were established within one year (by the end of 1989). The former PLO Office in Beijing (established in May 1965), which was an institution that enjoyed "diplomatic privileges", became the Embassy of Palestine on December 31 of 1988 (Minister of Foreign Affairs of PRC, 2014).

A more recent example of China's support for Palestine within the framework of the United Nations is the pass of UN General Assembly Resolution 67/19, which upgraded Palestine's status from "non-member observer entity" to "non-member observer state" (A/RES/67/19, 2012). This motion was seen as "largely symbolic" (Ethan \& Christine, 2012), because it could allow Palestine to start proceedings at the International Criminal Court against Israel under the claims of "war crimes" (Id.).

\subsection{Sino-Israeli Relation}

The relation between China and Israel is more complicated than the Sino-Palestine relations. Throughout history, China and Israel had their ups and downs.

"Although there are neither direct conflicts of national interests between China and Israel nor any religious and racial opposition between the Chinese people and the Jewish people, the development of mutual relationship is always restrained by some external factors." Israel was the first state in the Middle East that recognized the People's Republic of China. It was also the last state in the region that established diplomatic relationship with China. There was a 40-year delay of the negotiation for establishing diplomatic relationship (started in June 1950, finally established diplomatic relations in Jan 1992) for the two countries. The Korean War in early 1950s suspended the negotiations on establishing of diplomatic relationship between the two countries. And not until after the Madrid Peace Conference in 1991, when the Sino-Israeli diplomatic relationship was finally formed.

China has a mixed feeling about Israel. On one hand, China once considered Israel as a member of the "hostile camp" and resented its conduct to the Arab countries; on the other hand, China could not help to interact with Israel, who had been very "friendly" and helpful to China in many areas.

Israel's contact with China in the modern age includes relations with two Chinese governments: the Kuomintang government and the Communist government.

\subsubsection{With the Kuomintang Government}

During World War II, when thousands of Jewish refugees finally made it out of Europe, they desperately found themselves rejected by most of the countries. However, one city on the Chinese east coast opened its arms to embrace them. According to Shanghai Jewish Refugees Museum, over 20,000 Jewish refugees found their "Noah's Ark" in this city. They formed their own communities and received equal treatment as that to other foreigners. Ho Feng-Shan, a Chinese diplomat in Vienna, risked his own life and career by issuing thousands of visas to Austrian Jews. At that time, Shanghai did not require visas for foreigners to enter, but those visas were vital for Jewish families to flee Austria. In order to honor his heroic deeds, Ho was awarded with the title "Righteous among Nations" by Israel in 2000.

Moreover, Jews had special influence in China's historical revolutions. Since Jews suffered long-term discrimination and persecution in Eastern Europe, many of them became the backbone of the Russian Revolution in October 1917, which inspired China's National Revolution. The Soviet government sent many representatives to China to spread communism, many of these "missionaries" were Jews, including the Soviet Plenipotentiary in China Adolph Joffe, the Representative of Comintern Henk Sneevliet, and the Soviet Representative in 
Guangzhou Mikhail Borodin who also served as personal political adviser of Sun Yat-sen. As the first leader of the Kuomintang party (KMT), the founding father and the first president of the Republic of China (ROC), Sun maintained good personal relations with Mikhail for many years. It was very hard to analysis on what degree Sun was influenced by his Jewish adviser. However, there were people even went so far to believe that Jews was an important force behind the scene of magnificent revelations in modern China.

The Kuomintang government maintained a rather plain and friendly relationship with Jewish people. On November 29 of 1947, China abstained from voting on the Partition Resolution. Meanwhile, the Chinese Communist Party expressed their support for the founding of Israel by publishing articles on newspapers in the "liberated areas" (areas controlled by the Chinese Communist Party during China's civil war). CCP stated that Jewish people was fighting a righteous "war" against Arabs' anti-Semitism incited by the British government. Such position was consistent with Soviet Union's Middle East policy. After the UN General Assembly passed the Partition Resolution, Israel sent its first consul to Shanghai in order to help Jewish refugees to move to Israel. It was probably the first official contact of Israel with the Chinese Kuomintang government.

On March 1 of 1949, the Foreign Ministry of the Kuomintang government announced its recognition of the State of Israel. This friendly initiative was replied politely by Israel with an evasive attitude. At that time, Israel had gradually realized that the Kuomintang government was on a sinking ship. With vision, Israel decided to invest its time and efforts to China's future ruling party.

\subsubsection{With the Communist Party and the Later Peoples Republic of China (PRC)}

On January 4 of 1950, the legal adviser of Israeli Foreign Ministry signed the document of recognizing the new Communist Government as the legitimate representative of China and decided to be in favor of PRC on future dispute over China's seat in the United Nations (International Division-Asia Division: Position on China, 1950, Israel State Archives, Ministry of Foreign Affairs file 1561/9). Five days later, Israeli Foreign Minister Moshe Sharett telegraphed China's primer Zhou Enlai, announced Israel's position. As the first Middle Eastern country to convey friendliness to the newly born PRC, it was quite an encouragement for the Chinese people. One of the reasons for Israel's friendly approach was that Israel considered itself as a socialist country at that time. David Ben-Gurion, who served as Israel's first Prime Minister, was deeply influenced by left-wing theories himself.

The feeling was initially consensual. CCP was also full of goodwill towards Israel at the beginning. However, the friendship was soon replaced by the Cold War ideology. Israel's violations of territorial and national rights of the Arab countries made China decide to estrange Israel. The relations between PRC and Israel finally broke up when Israel supported the United States' armed aggression against North Korea (Democratic People's Republic of Korea, DPRK) in the Korean War in 1950. After the Asia-Africa (Bandung) Conference in 1955, China formally took the side of Arab countries and expressly supported Palestine people's right to return to their homeland. However, China refrained from denying Israel's right to exist and secretly pursued trade ties with Israel.

In 1953, Chinese Prime Minister Zhou Enlai met David Hacohen, who was Israeli Ambassador of Burma at that time, in the city of Yangon. The meeting led to a visit to China by an Israeli trade delegation in January 1955 (The Global Jewish News Source, 1955). Although the political relations between China and Israel were frozen, their economic relations started to warm up. After China and the Soviet Union fall foul of each other, China established diplomatic relations with the United States in 1979, which triggered the Sino-Israeli relations begin to thaw.

In 1985, Israel reopened its consulate in Hong Kong to facilitate relations with China. The consulate was used as "the main point for diplomatic and economic contacts" (Thomas, 1985) between the two countries. In 1987, Israel set up "the first official Government owned company (Copeco Ltd) to establish and foster commercial activities between companies in China and Israel". The company played an active role in promoting mutual benefits between the two countries until 1992, when the Sino-Israeli official diplomatic relationships were finally established.

Over the years, Israel and China have maintained good economic and trade cooperation. The annual bilateral trade volume between them has increased from 50 million US dollars when they first established diplomatic relations to today's nearly 8 billion US dollars (China News Network, 2013).

Besides economy, another major area of gaining mutual benefits between China and Israel is military technology. The communication and cooperation can be dated back to the 1980s, even before the formal diplomatic relations was established. After established the reform and opening up as the basic national policy, China's foreign tactics were also radically transformed. Specifically, China's military diplomacy took a more pragmatic strategy. It 
began to import arms from Western countries and to seek international military cooperation in mid-1970s. China also started to provide light weapons to fraternal socialist countries. By the $1980 \mathrm{~s}$, China was able to offer conventional and tactical defensive weapons to countries in Africa and the Middle East. After Soviet imposed an arm embargo on China during the Sino-Vietnamese war in 1979, China was in need of a new partner for developing military technology. Israeli military industry saw the potential of the Chinese market, and seizend the opportunity to form a bilateral military tie. Such endeavor also laid the foundation for future political contacts between the two countries. At first, Israel would sell a small amount of weapons to China, and provide technologies to China in regard to how to manufacture these arms, including missiles, tanks, artillery and various of radar equipment. Today, China has become "a vital market for Israel's extensive military industries and arms manufacturers" (Sudha, 2004). Correspondently, Israel has become China's second-largest arms supplier, next to Russia (Id.).

However, the Sino-Israeli military cooperation is not always plain sailing. Conflicts did occur when influential third-party was involved. One of these incidents was about "Phalcon".

The "Phalcon" incident caused serious damage to the military tie between Israel and China. One version of the story contains conspiracy theory: It began when China approached to Russia in desire of purchasing an Airborne Early Warning System. Such equipment was believed to have a profound influence on the situation of Taiwan Strait. In order to sabotage the negotiation, United States decided to encourage Israel to present China a better deal by offering to sell the "Phalcon" system.

The IAI EL/M-2750 Phalcon is an Airborne Early Warning and Control radar system developed by Israel, based on U.S. technology. China responded to Israel's offer with enthusiasm. It withdrew from the negotiation with Russia, and relaxed the domestic research work. After two years of lengthy negotiation, Israel unilaterally canceled the deal on December 18 of 2001, claimed facing the danger of losing 2.8 billion dollars yearly aid from the United States. Eventually, Israel sold the Phalcon system to India, who was considered as the main regional competitor of China.

As a result, China hosted a press conference to condemn Israel's perfidy. In this incident, China lost 250 million dollars as the prepayment, hundreds of billions of dollars as infrastructure investment, and two years of valuable time.

Fortunately, China and Israel were able to overcome all sorts of unpleasantness. China would not hold a grudge against Israel for too long simply because there is too many mutual benefits for the two countries to cooperate. Being Israel's largest trading partner in Asia and the world's third largest trading partner in the world, China is also one of the most favorable countries for Israel's foreign investments. Israeli invested projects in China are mainly focused on high-tech programs, new energy, and energy saving technology, agriculture, biomedicine, and environmental protection.

\section{Proposals for China's Future Middle East Policies: Keeping on the Realism}

On the political level, China still relies on the support and cooperation of Arab-Islamic countries in international affairs. Economically, China's largest overseas energy suppliers are located or connected to the Middle East region. It is also an important export commodity and engineering contracting labor market for China. On the level of national security, extremism in the Middle East has great influence on China's western regions, which poses potential threats to stability in border areas of western China. On the level of international system, Middle East is an arena for influential countries to play political games within the framework of the United Nations. It is also a stage for China to shape its image as a responsible big country.

China has a consistent position on the Israeli-Palestinian conflict that is promoting peace talks. In this May, the Chinese President Xi Jinping just put forward a four-point proposal on maintaining peace in the Middle East during Abbas' visit to Beijing: First, China will continue to support the independence of the State of Palestine, and emphasize the peaceful coexistence of Israel and Palestine. Second, the only way to achieve peace between Israel and Palestine is through political means, specifically negotiation. Third, China believes it is necessary to adhere to the guiding principle of "land for peace" promoted by UN Security Council Resolution 242. Fourth, the international community should provide safeguards to advance the peace process of the Middle East (Qian, 2013).

China has become the world's largest net importer of petroleum and other liquid fuels since 2013. It is still diversified with the sources of its crude oil imports "as a result of robust oil demand growth and recent geopolitical uncertainties." With the rapid economic growth, China's dependence on imported energy has increased to 58\%, and more than half of the energy imports are from the Middle East. In 2011, the trade between 
China and the Middle East has reached to 190 billion dollars, and it is expected to increase to 350-500 billion dollars in 2020. With such a huge interest involved, China is concerned with everything that happens in the Middle East. One should only expect China to play a more positive role in the region.

One thing about the Middle East conflict is that the problems are never purely political. It reflects the antagonistic relations among the three major religions in the world. Since China is not a religious country, it might have a more mutual and rational view on the whole matter. The main suggestion I would give is this: We should keep on following the realism. It is the only way to stay neutral and rational over such a complicated matter. Since promoting national interests is our ultimate goal, staying rational and relying on realism is the best way to forget all the distractions and keep our eyes on the ball.

\section{References}

China-Israel Relations. (n.d.). Retrieved from http://en.wikipedia.org/wiki/China-Israel_relations

China-Palestinian Relations. (n.d.). Retrieved from http://en.wikipedia.org/wiki/China-Palestine_relations

A/RES/3379. (1975, November 10). Retrieved from http://www.un.org/en/ga/search/view_doc.asp? symbol=A/RES/3379(XXX)\&referer=/english/\&Lang=E

A/RES/67/19. (2012, $\quad$ December 4$). \quad$ Retrieved http://unispal.un.org/UNISPAL.NSF/0/19862D03C564FA2C85257 ACB004EE69B

Anecdotes of the Establishment of China-Israel Diplomatic Relation. (n.d.). Retrieved from http://phtv.ifeng.com/program/zmdfs/detail_2012_03/05/12971081_0.shtml

Ethan, B., \& Christine, H. (2012). U.N. Assembly, in Blow to U.S., Elevates Status of Palestine (original title: U.N. Will Vote on Status for Palestinians, Defying U.S.). Retrieved from http://www.nytimes.com/2012/11/30/world/middleeast/Palestinian-Authority-United-Nations-Israel.html?p agewanted=all\&_r=1\&

Gang, Y. (2010). Restraint and Regret, Sixty-Year Relationship between China and Israel, Institute of West Asian and African Studies. Chinese Academy of Social Sciences.

International Division-Asia Division: Position on China. (1950, Jan. 4). Israel State Archives, Ministry of Foreign Affairs file, 1561/9.

Israel Scraps China Radar Deal. (2000, July 12). BBC News. Retrieved from http://news.bbc.co.uk/2/hi/middle_east/830609.stm

Minister of Foreign Affairs of PRC. (2014). Relationship Between China and Palestine. Retrieved from http://wcm.fmprc.gov.cn/pub/chn/gxh/cgb/zcgmzysx/yz/1206_4/1206x1/t6247.htm

Netanyahu: Israel Will Be China's Best Cooperating Partner. (n.d.). China News Network. Retrieved from http://news.xinmin.cn/domestic/2013/05/08/20150864.html

Qian, T. (2013). Xi emphasized that China would Continue to Firmly Support the Just Cause of the Palestinian People. Retrieved from http://news.xinhuanet.com/politics/2013-05/06/c_115654416.htm

S/RES/476. (1980). Retrieved June 30, 1980, from http://domino.un.org/UNISPAL.NSF/ b86613e7d92097880525672e007227a7/6de6da8a650b4c3b852560df00663826?OpenDocument

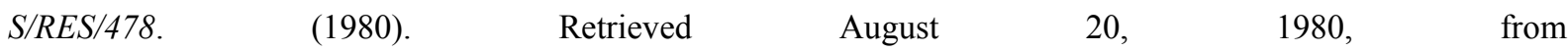
http://unispal.un.org/UNISPAL.NSF/0/DDE590C6FF232007852560DF0065FDDB

Sudha, R. (2014, December 21). US Up in Arms Over Sino-Israel Ties. Asia Times. Retrieved from http://www.atimes.com/atimes/Middle_East/FL21Ak01.html

Tang, S. (2003). Tribute to Edward Said: From the Opposition to Oslo Accord to Israeli-Palestinian Cohabitation. Cultural Studies Monthly, 32. Retrieved from http://www.cc.ncu.edu.tw/ csa/oldjournal/ 32/journal_park271.htm

The Global Jewish News Source. (1955). Israel Trade Delegation to Leave for Red China Today. Retrieved from http://www.jta.org/1955/01/20/archive/isaal-trade-delegation-to-leave-for-red-china-today

Thomas, L. F. (1985, July 22). Israel and China Quietly Form Trade Bonds. The New York Times. Retrieved from http://www.nytimes.com/1985/07/22/world/israel-and-china-quietly-form-trade-bonds.html

Wen, Z. X. (2012). Mao Zedong's Thoughts on Supporting Arab Countries and Against Israel's Expansionism. Retrieved from http://forum.home.news.cn/thread/107806988/1.html 


\section{Copyrights}

Copyright for this article is retained by the author(s), with first publication rights granted to the journal.

This is an open-access article distributed under the terms and conditions of the Creative Commons Attribution license (http://creativecommons.org/licenses/by/3.0/). 